\title{
BOOKS RECEIVED
}

\author{
Aestimatio 12 (2015)
}

Paola Bernardini and Anna Rodolfi edd. Roger Bacon's Communia Naturalium: A 13th Century Philosopher's Workshop. Florence: SISMEL - Edizioni del Galluzzo, 2014.

Estelle Bertrand and Rita Compatangelo-Soussignan edd. Cycles de la nature, cycles de l'histoire. De la découverte des météores à la fin de l'âge d'or. Bordeaux: Ausonius, 2015.

Luca Bianchi and Chiara Crisciani edd. Forme e oggetti della conoscenza nel XIV secolo. Studi in ricordi di Maria Elena Reina. Florence: SISMEL - Edizioni del Galluzzo, 2014.

Isabelle Boehm and Nathalie Rousseau edd. L'expressivité du lexique médical en Grèce et à Rome. Hommages à Françoise Skoda. Paris: Presses de l'Université Paris-Sorbonne, 2014.

Sonja Boon. Telling the Flesh: Life Writing, Citizenship and the Body in Letters to Samual Auguste Tissot. Montreal, PQ/Kingston, ON: McGill-Queen's University Press, 2015.

Carmen Cardelle de Hartmann and Philipp Roelli edd. Petrus Alfonsi and his Dialogus: Background, Context, Reception. Florence: SISMEL - Edizioni del Galluzzo, 2014.

José Chabás and Bernard R. Goldstein. Essays on Medieval Computational Astronomy. Leiden/New York: Brill, 2015.

Elizabeth M. Craik. The 'Hippocratic' Corpus: Content and Context. London, UK/New York: Routledge, 2015.

Kathryn A. Edwards ed. Everyday Magic in Early Modern Europe. Farnham, UK/Burlington, VT: Ashgate, 2015.

Silvia Fazzo. Il Libro Lambda della Metafisica di Aristotele. Naples: Bibliopolis, 2012.

Commento al Libro Lambda della Metafisica di Aristotele. Naples: Bibliopolis, 2014. 
Michael Hunter. Boyle Studies: Aspects of the Life and Thought of Robert Boyle (1627-91). Farnham, UK/Burlington, VT: Ashgate, 2015.

Ido Israelowich. Patients and Healers in the High Roman Empire. Baltimore, MD: Johns Hopkins University Press, 2015.

Danielle Jacquart. Recherches médiévales sur la nature humaine. Essais sur la réflexion médicale (XIIe-XVe s.). Florence: SISMEL - Edizioni del Galluzzo, 2014.

Bernardo Mota and Henrique Leitão. Francisco de Melo. Obras matemáticas: 1. Edição crítica e tradução. Lisbon: Biblioteca Nacional de Portugal/Centro de Estudos Classicos, 2014.

Stefano Rapisarda and Erik Niblaeus edd. Dialogues among Books in Medieval Magic and Divination. Florence: SISMEL - Edizioni del Galluzzo, 2014.

Roshdi Rashed. Histoire de l'analyse diophantienne classique: D'Abū Kāmil à Fermat. Berlin: Walter de Gruyter, 2013.

Matthias Schönhofer. Letters from an American Botanist: The Correspondence of Gotthilf Heinrich Ernst Mühlenburg (1753-1814). Stuttgart: Fritz Steiner Verlag, 2014.

Celia E. Schultz. Commentary on Cicero, De Divinatione I. Ann Arbor, MI: University of Michigan Press, 2014.

Tanja Skambraks. Die Kinderbischofsfest im Mittelalter. Florence: SISMEL -Edizioni del Galluzzo, 2014.

Zlata Blažina Tomić and Vesna Blažina. Expelling the Plague: The Health Office and the Implementation of Quarantine in Dubrovnik, 1377-1533. Montreal/Kingston/London/Ithaca: McGill-Queen's University Press, 2015.

Alfonso Tortora. L'eruzione vesuviana del 1631. Una storia d'età moderna. Rome: Carocci editore, 2014.

Mark A. Waddell. Jesuit Science and the End of Nature's Secrets. Farnham, UK/Burlington, VT: Ashgate, 2015.

Maria Zack and Elain Landry edd. Research in History of Philosophy and Mathematics. The CHSPM 2014 Annual Meeting in St Catharines, Ontario. New York: Birkhäuser, 2015. 